\title{
FEDERAL REGULATION OF BANKING: A PLEA FOR UNIFICATION
}

\author{
J. L. ROBERTSON*
}

I

Regulatory Philosophy

In the tradition of such political philosophers as Plato, Aristotle, Hobbes, Locke, Hamilton, and Madison, one might say that good government consists of good laws that are administered intelligently, conscientiously, and uniformly. The necessary body of good laws would deal with all matters appropriate for legislative treatment and only such matters. They would be clear and comprehensible to all who would be governed by them and should understand them.

Whether good laws, in this sense, can be enacted in a modern industrial nation is a question I shall leave to political scientists. For present purposes, I shall accept the structure, operations, and product of the legislative process as they are, and deal only with a field in which I have experience-the administration of civil laws by governmental agencies, and specifically the regulation of banking by our federal government. In this area, through accidents of history in conjunction with understandable human failings, a situation exists that has never been paralleled, as far as I can ascertain, in terms of complexity, confusion, irrationality, and difficulty of administration. Competing for the deposits of the banking public and for opportunities to lend those deposits profitably (and in many other fields) are thousands of institutions that are subject to the laws, regulations, and supervision of agencies of fifty states and of at least five federal agencies. A minority are principally governed by only one set of rules and one administrative body; most, however, are subject to a minimum of two sets of rules, administered by completely separate governmental organizations-generally agencies of different governments.

To be specific within reasonable compass, I shall not touch upon the situation of building associations, savings and loan associations, credit unions, and other "nonbank" institutions. Of our more than 13,000 commercial banks, ${ }^{1}$ the majority are governed by state laws and supervision, as well as by the Federal Deposit Insurance Act and numerous other federal laws, and are examined by the Federal Deposit Insurance Corporation ${ }^{2}$ as well as by state authorities. State banks that voluntarily

* Grinnell College, I925-I927; A.B., LL.B. I93I, George Washington University; LL.M. I932, Harvard University. Vice-Chairman, Board of Governors of the Federal Reserve System.

I am deeply indebted to Robert F. Sanders, Senior Attorney, Board of Governors of the Federal Reserve System, for able assistance in the preparation of this article.

${ }^{1}$ For a statistical breakdown as of June 30, 1966, see 52 Fed. RESERve BuLl. I248 (I966).

${ }^{2}$ The FDIC is authorized to examine all insured banks, I2 U.S.C.A. $\$ 1820$ (b) (Supp. I966), but usually exercises such authority only with respect to insured banks that are not members of the Federal Reserve System. 
join the Federal Reserve System ${ }^{3}$ deal principally with state and Federal Reserve laws and regulations, but they are subject in addition to the authority of the FDIC. ${ }^{4}$ All national banks-those chartered under federal law-are supervised by the Comptroller of the Currency, but since they are all members of the Federal Reserve System, they are also subject to the Federal Reserve Act and the authority and applicable regulations of the Federal Reserve System. ${ }^{5}$

The difficulties of federal bank supervision have advanced in geometric proportion as new layers of laws, administration, and judicial decisions have been added. The Federal Reserve Act of $1913,{ }^{6}$ the Banking Acts of the r930s (which included the creation of the Federal Deposit Insurance Corporation), ${ }^{7}$ the Bank Holding Company Act of $x 956,{ }^{8}$ and the Bank Merger Act of 1960 and its 1966 amendment ${ }^{0}$ have contributed to an almost impenetrable maze of legislation and consequent administration.

For several decades, a large part of the time and energies of those involved in federal regulation of banking has been devoted to accommodation of their activities to the stresses that this legislative and administrative situation inevitably produced. In an earlier period, bankers used to refer to the three basic C's of lending-character, capacity, and collateral. With sardonic humor, federal bank regulators have referred to the three C's of consultation, cooperation, and coordination.

Until quite recent years, a modus vivendi was precariously maintained, although it often led to a lowest-common-denominator level of standards for bank regulation and supervision. In the ig6os the jerry-built structure all but collapsed in a cloud of conflicting interpretations and pronouncements, confusion, and recrimination. Perhaps this was inevitable because the structure rests on an inherently defective foundation.

The deterioration in the effectiveness of federal regulation of banking occurred, it seems to me, for two reasons-organizational shortcomings and individual shortcomings of supervisors. When laws and regulations apply to two or more groups of institutions (for example, national banks and member state banks, or member banks and insured nonmember banks) trouble and ineffective administration can hardly be averted when interpretation and application of the governing rules are distributed among two or three coordinate governmental agencies. This is the basis for the conclusion, arrived at later in this article, that unification of federal banking regula-

\footnotetext{
${ }^{3} 12$ U.S.C. $\$ 32 \mathrm{r}(1964)$.

"State banks admitted to membership in the Federal Reserve System are insured banks under the Federal Deposit Insurance Act. I2 U.S.C. $\$ 18 \mathrm{r}_{4}(\mathrm{~b})(1964)$.

${ }^{5} I_{2}$ U.S.C. $\$ \S 282,5012$ (1964). National banks are also all insured by the Federal Deposit Insurance Corporation. As such, they are subject to the authority of the FDIC, but they are principally regulated by the Comptroller and the Board of Governors.

${ }^{\circ}$ Ch. $6,3^{8}$ Stat. 261 (Igr3) (codified in scattered sections of 12,31 U.S.C.).

7 Banking Act of $x 933$, ch. 89, 48 Stat. 162 (codified in scattered sections of $x 2,39$ U.S.C.); Banking Act of I935, ch. 614, 49 Stat. 684 (codified in scattered sections of II, I2, I5, 39 U.S.C.).

8 I2 U.S.C.A. $\$ \$ 1841-49$ (Supp. 1966).

${ }^{\circ} x_{2}$ U.S.C.A. $\$ 1828$ (c) (Supp. 1966).
} 
tion is essential for uniform and equitable application of laws and regulations designed to maintain a sound and serviceable banking system for the nation.

Bank supervisors are almost daily confronted with the necessity of making decisions that involve basic questions of social and governmental philosophy. For this purpose, I shall disregard the special difficulties that arise when administrators succumb to the temptation to use official power for personal aggrandizement-an astonishingly rare occurrence, fortunately. But the most conscientious administrator-in the regulation of banking, at any rate-encounters again and again the need for choosing between acting in obedience to well-defined law and acting in a way that, in his judgment, would best solve an immediate problem or improve what he deems a bad situation.

An example may be illuminating. Section I9 of the Federal Reserve Act provides that "No member bank shall, directly or indirectly, by any device whatsoever, pay any interest on any deposit which is payable on demand." 10 Whether or not this strongly stated prohibition was justified when it was enacted in $1933{ }^{11}$ a federal bank supervisor might rationally reach the conclusion that the continued existence of this prohibition is not in the public interest. Let us assume further that a realistic appraisal of the political situation makes clear that there is practically no possibility that Congress can be persuaded to repeal the prohibition in the foreseeable future. Under Federal Reserve Regulation Q, the term "demand deposit" includes any deposit that the depositor has a legal right to reclaim in less than thirty days. ${ }^{12}$ In a tight-money situation, competitive forces are such that some commercial banks become convinced that it is to their interest to pay interest on such deposits-moneys that must be repaid ten days after their deposit, let us say. In order to avoid the statutory prohibition, the bank does not solicit such funds as deposits, eo nomine, but offers instead to issue promissory notes maturing in ten days.

Many readers will recognize this as an actual incident of recent years. Although hidden in wordy obfuscation, there is general recognition of the reality: Some banks wish to pay interest on demand deposits and hope that governmental supervisors will not interfere if they disguise the operation by using a traditionally nondeposit type of instrument.

This is the administrator's dilemma: As a matter of economic effect, he believes the country would benefit if banks could attract such funds by paying interest thereon, but he also knows that the banking fraternity-and others-would conclude, if this dodge were permitted, that extant laws and regulations sometimes are not enforced if government officials disagree with the policy of those laws. The unfortunate side effects of such a situation are compounded in the field of banking by the notoriety of the resulting conflicts among the regulators and by the pressures attendant on the unique ability of the regulated to select their regulators on the

\footnotetext{
${ }^{10} \mathrm{I2}$ U.S.C. $\$ 371 \mathrm{ra}(1964)$.

${ }^{11}$ Ch. 89, § II (b), 48 Stat. I8I (1933).

${ }^{13}$ I2 C.F.R. \& 217.1 (I963).
} 
basis of which one is most willing to stretch the law to suit them. While no one can deny that regulators do have some discretion in interpreting the law, the presence of this power, even where regulatory authority is not divided as it is in banking, involves a question of political philosophy in the most fundamental sense; in banking we have the dichotomy between a government of laws and a government of men in an even more diffcult form. It is my own philosophy that, given the structure of banking regulation, respect for and observance of law and dependence on legislative change will in the long run yield benefits that justify enduring temporary social or economic detriments.

The United States has such a long tradition of obedience to law that we take for granted the advantages that flow from that national attitude and practice. As our economic and regulatory machinery become more complicated, opportunities multiply for cutting corners. This is a tempting situation, unless civic virtue prevails over the prospect of immediate personal or bureaucratic gain. The central tenet of the regulatory philosophy of the Federal Reserve System is that governmental organizations, and those in the banking field above all, have a duty to interpret and enforce laws honestly and uniformly and to seek correction of unwise or unjust laws through orderly legislative process. This firm conviction and a determined effort to implement that conviction in our work is the basic regulatory philosophy of the Federal Reserve System.

The actual operation of that philosophy in the Federal Reserve's performance of its regulatory functions can perhaps be more concretely presented through a description of a few crucial situations encountered in our work within recent years that are currently matters of controversy and difficulty in federal regulation of banking. Each that I have selected involves provisions of the Banking Act of 1933 that some believe were ill-conceived and that many consider have outlived their usefulness. Each illustrates, in a somewhat different way, the structural and operational shortcomings of our existing regulatory structure, and demonstrates, I believe, the crying need for unification of federal regulatory functions in a Federal Banking Commission, as proposed and described in the last portion of this article.

\section{II}

A Sampling of Bank Supervisory Actions of the Board of Governors

A. Classification of Certain Promissory Notes Issued by Banks as "Deposits" for Purposes of Regulations D and Q

From its inception, section $x g$ of the Federal Reserve Act has required banks that are members of the Federal Reserve System to maintain reserves against their "demand deposits" and their "time deposits." By the Banking Act of I933, Congress added to section Ig the provision that "No member bank shall, directly or

\footnotetext{
${ }^{13}{ }_{12}$ U.S.C.A. $\$ 46$ I (Supp. 1966).
} 
indirectly, by any device whatsoever, pay any interest on any deposit which is payable on demand." ${ }^{14}$ This flat prohibition has remained unchanged despite proposals for its repeal. ${ }^{15}$ The Banking Act of 1933 also added to section I9 a provision directing the Board of Governors to regulate "the rate of interest which may be paid by member banks on time deposits."16 By the Banking Act of 1935 this directive was made applicable to both "time and savings deposits."17

The Banking Act of I935 further amended section I9 to authorize the Board of Governors,

for the purposes of this section, to define the terms "demand deposits", "gross demand deposits", "deposits payable on demand", "time deposits", "savings deposits", and "trust funds", to determine what shall be deemed to be a payment of interest, and to prescribe such rules and regulations as it may deem necessary to effectuate the purposes of this section and prevent evasions thereof. ${ }^{18}$

Before that time, section $x 9$ had itself differentiated between "demand deposits" and "time deposits." Deposits payable within thirty days were demand deposits; deposits payable after thirty days were time deposits. ${ }^{19}$ Since 1935 , Federal Reserve Regulation D, "Reserves of Member Banks," and Regulation Q, "Payment of Interest on Deposits," have maintained this thirty-day differentiation. ${ }^{20}$

Until recent years there was general recognition on the part of the banking community that money placed in a bank that is used in the ordinary course of its banking business is a deposit for the purposes of rules governing reserves against and payment of interest on deposits. However, beginning in September I964, banks began to issue instruments that were called short-term unsecured promissory notes. ${ }^{21}$ The reserves required by section $x 9$ of the Federal Reserve Act were not maintained against funds received for these notes, and the rates of interest paid on them exceeded the maximum permissible rates on deposits of like maturity. (Of course, any interest on such a note with a maturity of less than thirty days exceeded the maximum permissible rate on a deposit of like maturity, because such a deposit is a "demand deposit," on which the payment of interest is prohibited.)

In time, it became clear that such promissory notes, which involved the same

\footnotetext{
${ }^{14}$ I2 U.S.C. $\$ 371 \mathrm{ra}(1964)$.

${ }^{15}$ E.g., H.R. 9687, 88th Cong., 2d Sess. (rg64).

${ }^{10}$ Banking Act of 1933 , ch. $89, \S \mathrm{II}(\mathrm{b}), 48$ Stat. 182.

${ }^{17}$ Banking Act of 1935, ch. 6I4, $\$ 324,49$ Stat. 7I4. By Act of September 2I, I966, Pub. L. No. $89-597$, $\$ 2$ (c), 80 Stat. 823, Congress suspended the mandatory directive temporarily (for one year) in favor of permissive authority. I2 U.S.C.A. $\$ 37$ Ib (Supp. 1966); see note following I2 U.S.C. $\$ 46 \mathrm{I}$ (Supp. 1966).

${ }_{18}$ Banking Act of 1935, ch. 6r4, $\$ 324,49$ Stat. 714. By Act of September 21, 1966, Pub. I. No. $89-597, \$ 2(a), 80$ Stat. 823 , the Board's definitional authority under section 19 was changed temporarily (for one year) to read in terms of authority "to define the terms used in" particular sections of the statute. I2 U.S.C.A. $\$ 46 \mathrm{r}$ (a) (Supp. I966) and note following $\$ 46 \mathrm{r}$.

${ }^{10}$ Federal Reserve Act of I913, ch. 6, $\S 19,38$ Stat. 270; Act of June 21, I9I7, ch. 32, $\S$ Io, 40 Stat. 239.

20 I2 C.F.R. $\$ 204$ (I963); I2 C.F.R. $\$ 217$ (I963).

${ }^{21}$ See Bratter, Should Banks Be Allowed to Issue Promissory Notes?, Banking, Nov. I965, at 49.
} 
debtor-creditor relationship between the bank and its customer as that which exists under conventional deposit contracts, were being used to circumvent section ig and Federal Reserve Regulations D and Q. To consider such notes as nondeposit borrowings would have meant that banks in states where no limitation is imposed on state banks' borrowing powers ${ }^{22}$ could readily convert all of their certificates of deposit into notes, pay whatever rates of interest they wished, and not maintain any reserves against them. There would even seem to be no reason why a bank might not convert all of its deposits, including checking accounts, into such notes. These potential evasions of the law became particularly significant when the Comptroller of the Currency ruled that short-term unsecured promissory notes are not subject to the borrowing limitation placed on national banks ${ }^{23}$ after having already ruled that such notes are not deposits. ${ }^{24}$

The Board of Governors was thus presented with the question whether it could properly sit by and thereby condone an erosion of the statutory and regulatory re-

${ }^{22}$ A compilation of state statutes respecting limitations on amounts banks can borrow, which was prepared in the Legal Division of the Board of Governors of the Federal Reserve System in October 1964 , revealed that at that time thirteen states imposed no statutory limitation on borrowing by banks: Alabama, Arkansas, Connecticut, Delaware, Illinois, Indiana, Kentucky, Massachusetts, Missouri, New Jersey, New York, Rhode Island, and South Carolina.

${ }^{23}$ I2 U.S.C. $\$ 82$ (1964) provides that

"No national banking association shall at any time be indebted, or in any way liable, to an amount exceeding the amount of its capital stock at such time actually paid in and remaining undiminished by losses or otherwise, plus 50 percent of the amount of its unimpaired surplus fund, except on account of demands of the nature following:

First. Notes of circulation.

Second. Moneys deposited with or collected by the association.

Third. Bills of exchange or drafts drawn against money actually on deposit to the credit of the association, or due thereto.

Fourth. Liabilities to the stockholders of the association for dividends and reserve profits.

Fifth. Liabilities incurred under the provisions of the Federal Reserve Act.

Sixth. Liabilities incurred under the provisions of the Federal Deposit Insurance Act.

Seventh. Liabilities created by the indorsement of accepted bills of exchange payable abroad actually owned by the indorsing bank and discounted at home or abroad.

Eighth. Liabilities incurred under the provisions of section 202 of Title II of the Federal Farm Loan Act, approved July I7, r9r6, as amended by the Agricultural Credits Act of r923.

Ninth. Liabilities incurred on account of loans made with the express approval of the Comptroller of the Currency under paragraph (9) of section 5200 of the Revised Statutes, as amended.

Tenth. Liabilities incurred under the provisions of section $\mathbf{z}_{3} \mathrm{~b}$ of the Federal Reserve Act."

3 Nat'z BANKING REv. II7 (I965) contains the following paragraph:

"The Comptroller has also recently issued an interpretation of 12 U.S.C. 82 which imposes limitations on total borrowings by national banks. The ruling relates to unsubordinated promissory notes of comparatively short term. Noting that such notes are issued in the ordinary course of banking as a means of obtaining funds to be made in making loans and the performance of other banking functions, it was held that such negotiable or nonnegotiable promissory notes issued by national banks represent liabilities excepted from the limitations contained in I2 U.S.C. 82."

So interpreted, I2 U.S.C. $\$ 82$ ( 1964$)$ constitutes no obstacle to unlimited issuance of such notes; a national bank could shift all of its deposits into the promissory note category.

${ }^{24}$ Comptroller of the Currency, Manual for National, Banks para. 7530 (1966). Note the following language especially:

"Notwithstanding the provisions of Regulations $Q$ and $D$ issued by the Federal Reserve Board, it is the position of the Comptroller of the Currency that the proceeds of such notes do not constitute deposits and that the provisions of 12 U.S.C. $46 \mathrm{r}, 462$ and $18 \mathrm{r}_{3}$ relating to reserves, interest limitations, and deposit insurance are not applicable." 
quirements governing reserves against and payment of interest on deposits, which was being accomplished simply by changing labels on instruments issued by banks to their customers from "deposit" to "note."

Some bankers and bank supervisors favor repeal of the prohibition against payment of interest on demand deposits. ${ }^{25}$ Whether the prohibition serves a beneficial purpose is questionable, and it has proved almost impossible to administer effectively. More bankers and bank supervisors favor placing the Board's authority to regulate the interest rates payable on time deposits on a stand-by basis-that is, making such regulation discretionary ("may") rather than mandatory ("shall"). ${ }^{26}$ Nevertheless, while these laws and the regulations promulgated thereunder are on the books, the Federal Reserve has the responsibility of making them effective. This requires that, with few exceptions, all indebtedness of member banks, irrespective of its documentary form, must be considered and treated by the Board as deposits subject to Regulations $\mathrm{D}$ and $\mathrm{Q}$.

Incidental to the Board's deliberations on this matter, a suggestion was made that permitting banks to issue promissory notes at any rate of interest they desired up to the limits of their borrowing powers would provide them with a desirable escape hatch from the rules governing reserves against and payment of interest on deposits. To me, even if all banks were subject to the same limitation on the extent to which they might issue promissory notes, adoption of such an escapehatch approach to the law would have been as wrong in principle as if the Board had adopted the indefensible view that banks' receipts evidenced by "notes" are significantly different, for these purposes, from receipts that are called "deposits" and should not be considered deposits. In both instances, the Board would have failed to carry out the congressional mandate to limit rates of interest on time deposits and to prevent evasion of the prohibition against payment of interest on demand deposits.

The Board's action requiring inclusion as deposits, with certain exceptions, of "any promissory note, acknowledgment of advance, due bill, or similar instrument that is issued by a member bank principally as a means of obtaining funds to be used in its banking business" ${ }^{27}$ may not have been the best solution available. In the course of our study of the problem, the issues underlying a comprehensive definition of the term "deposit" became clear. The approach adopted by the Board does not resolve all of the known problems, which a more comprehensive definition could have. Nevertheless, the action was taken with the knowledge that, as indicated in the

${ }^{25}$ See Committee on Financial Institutions, Report to the President 20-22 (1963).

${ }^{20}$ Id. at 24. See also Commission on Money and Credir, Money and Credit: Their Infiuence on Jobs, Prices, ANd Growth 167 (Report of the Comm'n on Money and Credit, I96r). By Act of September 21, 1966, Pub. L. No. 89-597, \$2(c), 80 Stat. 823, the Congress changed "shall" to "may" for one year from that date. I2 U.S.C.A. $\$ 37$ Ib (Supp. I966); see note following I2 U.S.C.A. $\S 46$ I (Supp. Ig66).

${ }^{27} 3$ I Fed. Reg. 9103 (Ig66). 
Board's initial proposal with respect to bringing promissory notes within the coverage of Regulations $\mathrm{D}$ and $\mathrm{Q}$, it could adopt similar amendments with respect to other forms of indebtedness if they are used as a means of avoiding laws or regulations relating to reserves against and interest on deposits. ${ }^{28}$

\section{B. Bank Underwriting of Revenue Bonds}

The establishment of rules governing the payment of interest on deposits was only one of several major purposes of the Banking Act of 1933 . Another was the divorcement of commercial banking and investment banking. Among a number of changes directed at this objective, paragraph seventh of section $5^{1} 3^{6}$ of the United States Revised Statutes was amended to provide that a national bank "shall not underwrite any issue of securities,"20 and section 9 of the Federal Reserve Act was amended to provide that "State member banks shall be subject to the same limitations and conditions with respect to the purchasing, selling, underwriting, and holding of investment securities and stock as are applicable in the case of national banks under paragraph 'Seventh' of section 5136 of the Revised Statutes, as amended."30 An exemption from the prohibition was made for "obligations of the United States, or general obligations of any State or of any political subdivision thereof."

On the basis of these provisions, for almost thirty years the same restrictions on underwriting were applied to both national and member state banks; but today they are not. The formerly uniform (and still the Federal Reserve) view is that the term "general obligations of any State or of any political subdivision thereof" includes only obligations that are supported by an unconditional promise of payment made by a governmental entity that possesses general powers of taxation, including property taxation. ${ }^{32}$ Under this interpretation, bonds payable only from specified sources such as the income from designated facilities, commonly referred to as revenue bonds, are not eligible for bank underwriting. Under the Comptroller's current interpreta-

\footnotetext{
${ }^{28}$ See 3x Fed. Reg. xoro (1966). The comprehensive definition that I personally believe would have been most in keeping with the law would have been as follows: "The term 'deposit' means any indebtedness of a member bank that arises out of a transaction in the ordinary course of its banking business with respect to either funds received or credit extended by the bank, except ( $I$ ) indebtedness duc to a Federal Reserve Bank; (2) indebtedness due to another bank for its own account that is not reflected on books or reports of the debtor as a deposit; (3) indebtedness that arises from a loan, for one business day, of proceeds of a transfer of deposit credit in a Federal Reserve Bank (or of other immediately available funds) in connection with payment on that day for securities; and (4) indebtedness with an original maturity of more than two years that is subordinated to the claims of depositors." A footnote to the word indebtedness would have provided, "For the purposes of this definition, an indebted. ness does not include (I) an obligation to deliver securities or foreign exchange sold, (2) a contingent liability such as arises from the issuance of a letter of credit or a commitment to make a loan, or (3) a liability such as arises from the creation of a bank acceptance."

${ }^{29}$ I2 U.S.C. $\$ 24(1964)$.

${ }^{30}$ I2 U.S.C. $\$ 335(1964)$.

31 I2 U.S.C. $\$ 24\left(\mathrm{r}_{96}\right)$.

${ }^{32}$ See Hearings on Increased Flexibility for Financial Institutions Before the House Comm. on Banking and Currency, 88th Cong., Ist Sess. Ior8 (1963); 5 I Board of Governors of the Federal Reserve System ANn. Rep. 206 (I964); 52 id. 238 (I965).
} 
tions and Investment Securities Regulation, ${ }^{33}$ however, national banks are permitted to underwrite such bonds.

Insofar as the Comptroller's Regulation purports to expand the limited category of securities that section 5136 permits banks to underwrite, so as to authorize bank underwriting of revenue bonds and bonds that are payable only from one of several taxes that may be levied by the issuer, the Regulation is without legal authority, and the Board of Governors has so advised member state banks. ${ }^{34}$

Although the Senate debate on bills that led to the Banking Act of I933 contains considerable discussion of the meaning of "general obligations," the significance of the discussion is questionable. It occurred in the 72 nd Congress, and culminated in deletion of the word general. ${ }^{36}$ In the 73 d Congress, the Senate and the House versions of the legislation were identical with respect to the exemption from underwriting; neither included the word general. ${ }^{37}$ However, when the bill emerged from the conference committee that was appointed to resolve the differences between the two versions, the word general had been inserted. ${ }^{38}$ This change was neither explained in the Conference Report, ${ }^{39}$ nor discussed in debate. ${ }^{40}$

The best conclusion to be drawn from this is that Congress deliberately included the word general in the law and that therefore the word must be given the limiting. effect necessary to make it meaningful. It seems axiomatic that general obligations. must be distinguished from special obligations. The only reasonable basis upon which to distinguish between special and general obligations is on the basis of whether the promise of the issuer to pay is qualified or unqualified. Thus, if an obligor limits its promise to pay to certain of its resources, such as the proceeds of one tax, the obligation is a special obligation and cannot be considered eligible for bank

\footnotetext{
${ }^{33}$ I2 C.F.R. pt. I (Supp. I966). See in particular the interpretation and application of such regulation with respect to bonds of the Port of New York Authority. I2 C.F.R. $\$$ I.I67 (Supp. I966).

${ }^{34}$ I 2 C.F.R. $\$ 208.107$ (Supp. 1966). Section 208.107(b)(5) reads in part as follows: "Since the Comptroller is not authorized by law to expand the category of exempt securities established and described in paragraph Seventh of R.S. 5I36, the current [Comptroller's] regulation does not have the force and effect of law insofar as it attempts to do this. Accordingly, member State banks are informed that, in the opinion of the Board of Governors, the only securities that are exempt from the limitations and restrictions of paragraph Seventh are those specified in R.S. 5I36."

${ }^{35}$ For the various views of various Senators, see particularly 76 CoNG. REc. 2000, 2090-92, 240I-03 (1933). Perhaps the most perceptive comment was made by Senator Copeland when he stated, "I wish for myself that the word [general] might be omitted, because I feel confident that it is going to lead to trouble." Id. at 2092.

${ }^{30} \mathrm{Id}$. at 2403 .

${ }^{37}$ S. 245, 73d Cong., Ist Sess. (1933), introduced by Senator Glass on March II, 1933, 77 Cong. REc. I96 (I933); H.R. 566r, 73d Cong., Ist Sess. (1933), introduced by Representative Steagall on May I7, I 933 , id. at $36 \mathrm{rr}$.

${ }_{38}$ Id. at 5779. The phrase "general obligations of a State or of any political subdivision thereof" was already a part of section 5136 . It was included in 1927 as an exemption from the limitations imposed by the McFadden Act on national bank investment in securities. Act of Feb. 25, I927, ch. I9I, 44 Stat. 1224 (1927). The significance of the phrase became much greater, of course, as an exemption from the limitations imposed on inderwriting.

${ }^{30}$ H.R. Rep. No. 254, 73d Cong., Ist Sess. (1933); 77 CoNg. Rec. 5769 (I933).

${ }^{\circ 0}$ It is somewhat interesting to note that Senator Walsh of Montana, the sponsor of the amendment to delete general, died between the $72 \mathrm{~d}$ and $73 \mathrm{~d}$ Congresses. 77 Covg. Rec. 33 (1933).
} 
underwriting. ${ }^{41}$ Only obligations supported by an unqualified commitment by the obligor to pay (generally referred to as a pledge of the obligor's full faith and credit) can constitute general obligations.

But not every obligation supported by the unqualified promise of the obligor can be considered a general obligation for the purposes of the phrase "general obligations of any State or of any political subdivision thereof." If it were, the word general could be rendered meaningless and practically all governmental securities could be made eligible for bank underwriting in the following way: Whenever a taxing authority wished to issue obligations and to pledge only its income from a particular source, it could create a new authority or other entity and grant to its new creature the revenues from that limited source, and the new entity would issue bonds bearing its unqualified promise to pay. If any unqualified governmental promise were sufficient to give "general-obligation" status, this device could defeat the legislative intent by making all governmental securities eligible for bank underwriting, no matter how limited the obligation of the issuer.

Consequently, for the word general in the phrase "general obligations of any State or of any political subdivision thereof" to be meaningful, it must be considered as conveying two requirements: ( $\mathrm{r}$ ) the obligation must be supported by the unqualified commitment of the issuer to pay, and (2) the issuer of the obligation must possess general powers of taxation. ${ }^{42}$

Interpretations by the Comptroller of the Currency contemporaneous with the Banking Act of 1933 were along the lines of these requirements. ${ }^{43}$ Except for a period between 1934 and I938, when certain revenue bonds were held to be general obligations, both the Comptroller and the Board of Governors continued to apply these two tests until the Comptroller's Office changed its position in $1963 .{ }^{44}$ "To reverse such contemporaneous and long-standing interpretations in favor of an interpretation that in many situations makes the word general meaningless is an unwarranted exercise of administrative power.

\footnotetext{
${ }^{11}$ See I2 C.F.R. $\$ 208.105$ (Supp. I966).

12 Judicial support for this position is contained in Baker, Watts \& Co. v. Saxon, 261 F. Supp. 247 (D.D.C. I966), in which the court adopted verbatim a legislative recommendation of the Board of Governors relating to an amendment to I2 U.S.C. $\$ 24$ (I964) to clarify existing law along these lines. Sce 52 Bonrd of Governors of the Federal Reserve System Ann. Rep. 238 (I965). (At this writing, the question whether this decision will be appealed has not been resolved.) The unscemliness of the difference between the Board of Governors and the Comptroller was adverted to by Judge Holtzoff as follows: "This litigation presents an unusual situation in that two agencies of the Government,-the Federal Reserve System and the Comptroller of the Currency, - that administer the pertinent statutes adopt and apply divergent interpretations of a crucial provision. Consequently, the outcome of this lawsuit will not only constitute an adjudication of the rights of the parties, but will also effect a resolution of conflicting vicws of the two Government agencies." 26I F. Supp. at 248. And again: "Thus, we find the anomalous and chaotic situation of the statute being applied in one way to State banks that are members of the Federal Reserve System, and in an entirely different manner to national banks, merely because two different agencies administer the law in respect to these two groups of institutions." Id. at 250.

${ }^{\text {is }}$ See Hearings on Increased Flexibility for Financial Institutions Before the House Comm. on Banking and Currency, 88th Cong., rst Sess. 1046-47 (1963).

14. Id. at 1047.
} 
While I became convinced several years ago that banks should be permitted to underwrite certain classes of revenue bonds, I have continued to urge adherence to the Board's position that, under present law, banks may not underwrite such bonds. Under our system of government, the appropriate means for permitting banks to underwrite revenue bonds is not for administrators to "reinterpret" the law in accordance with their legislative-policy preferences. The remedy is action by Congress amending the law. Repeated efforts in this direction since 1955 have

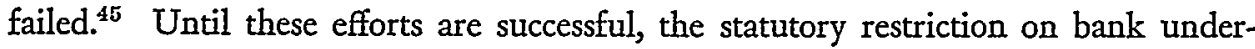
writing to "general obligations" must be given its effect unless we are prepared to abandon the principle that ours is a government of laws and not of men.

The Federal Reserve is aware that the difference of view between it and the Comptroller as to the meaning of the law has resulted in competitive inequality between member state banks and those national banks that decide to act under the Comptroller's ruling, despite Congress's specific statement that the rules governing underwriting of securities shall be the same for both. ${ }^{46}$ Some might argue that, because this inequality is contrary to the clear congressional intent, the Board acts improperly when it publishes rulings contrary to those of the Comptroller in the underwriting area. Such an argument, however, is equivalent to saying that whatever rules the Comptroller adopts in this area, even where they lack legal basis, should be followed by the Board of Governors with respect to member state banks. The Board's position ${ }^{47}$ is that Congress intended member state banks to be subject to all valid rules governing underwriting activities of national banks. It surely did not intend the Board, simply for the sake of equality of treatment, to permit member state banks to do something that the Board considered that national banks were being permitted to do on the basis of a regulation or interpretation that was promulgated without legal authority.

\section{Bank Purchase of Corporate Stocks}

Another provision of the Banking Act of 1933 that has led to a major divergence of view between the Board of Governors and the Comptroller in recent years is the so-called stock-purchase prohibition that was added to paragraph seventh of section 5136 of the Revised Statutes: "Except as hereinafter provided or otherwise permitted by law, nothing herein contained shall authorize the purchase by ... [a national bank] for its own account of any shares of stock of any corporation." ${ }^{38}$ As with the

\footnotetext{
${ }^{45}$ See, e.g., S. 2290, 84th Cong., Ist Sess. (1955); S. 202r, 85th Cong., Ist Sess. (1957); S. 828, 88th Cong., Ist Sess. (1963); H.R. 5845, 88th Cong., Ist Sess. (1963); H.R. 7539, 89th Cong., Ist Sess. (1965). 10 I2 U.S.C. $\$ 335$ (I964).

${ }^{47}$ See 12 C.F.R. $\$ 208.107$ (b) (5) (Supp. 1966); Hearings Before the House Comm. on Banking and Currency to Permit National Banks to Underwrite and Deal in "Revenue Bonds," 8gth Cong., Ist Sess. 63-64 (1965).

${ }^{48}$ I2 U.S.C. $\$ 24$ (1964).
} 
limitations on bank underwriting, this provision is made applicable to member state banks by the twentieth paragraph of section 9 of the Federal Reserve Act. ${ }^{40}$

For almost thirty years, in numerous situations, both the Comptroller and the Board of Governors interpreted the above-quoted sentence as prohibiting the purchase of any shares of corporate stock except to the extent authorized by provisions of the federal statutes. Such statutes specifically authorize the purchase of stock of Federal Reserve Banks, ${ }^{50}$ certain foreign banks and foreign banking corporations, ${ }^{51}$ safe deposit companies, ${ }^{52}$ bank premises subsidiaries, ${ }^{53}$ small business investment companies, ${ }^{54}$ and bank service corporations. ${ }^{55}$

On occasion the contention has been advanced that the prohibition was intended only to prevent banks from investing in corporate stock for income and capital appreciation. The formerly uniform (and still the Federal Reserve) view is that, although the prevention of such investment in stocks of money owed to depositors unquestionably was a major congressional purpose, the stock-purchase prohibition is correctly interpreted as preventing also the purchase of stock of other banks or of corporations created to perform functions that could be performed by the bank itself. ${ }^{56}$

The Comptroller, however, has ruled that national banks may create and own subsidiary corporations to serve the bank. ${ }^{57}$ He reasons that if a bank may perform an activity directly, it may separately incorporate the activity and thus perform it indirectly. He considers that a national bank may do this on the basis of its authority to exercise "all such incidental powers as shall be necessary to carry on the business of banking."

In my view, the Comptroller's position fails to give effect to the objective of the Banking Act of 1933 "to separate as far as possible national and member banks from affliates of all kinds." "The stock-purchase prohibition, together with a number of other provisions of the 1933 Act, ${ }^{60}$ served to restrict the affliate system by preventing

\footnotetext{
${ }^{19} 12$ U.S.C. $\$ 335$ (I964).

${ }^{80} \mathrm{I} 2$ U.S.C. $\$ 282$ (1964).

${ }^{51}$ I2 U.S.C. $\$ 6 \mathrm{r} 8(1964)$; 12 U.S.C.A. $\$ 601$ (Supp. 1966).

52 I2 U.S.C. $\$ 24(1964)$.

${ }^{68} I d$.

${ }^{5}{ }_{15}$ U.S.C. $\$ 682(1964)$.

${ }^{65} \mathrm{I} 2$ U.S.C. $\$ 1862$ (1964).

${ }^{60}$ See 31 Fed. Reg. I002I (1966).

${ }^{67}$ For the Comptroller's view with respect to the stock of a mortgage service company and appraisal of that view by the House Banking Committee staff, see Hearings on Consolidation of Bank Examining and Supervisory Functions Before the Subcomm. of the House Comm. on Banking and Currency, 89th Cong., xst Sess. 388 (1965) [hereinafter cited as 1965 Hearings on Consolidation of Bank Examining and Supervisory Functions]. For a confirmation of his position on the general question, see 31 Fed. Reg. II459 (I966).

${ }_{68} \mathrm{I} 2$ U.S.C. $\$ 24\left(\mathrm{Ig}_{4}\right)$. A leading case on the meaning of this clause is Texas \& Pac. Ry. v. Pottorff, 29r U.S. 245 (r934), in which the Supreme Court, in denying a contention that national banks, on the basis of this clause, have the power to pledge assets to secure a private deposit, stated, "The measure of their powers is the statutory grant; and powers not conferred by Congress are denied." Id. at 253.

${ }^{50}$ S. ReP. No. 77, 73d Cong., Ist Sess. ro (1933).

${ }^{\circ 0} \mathrm{See}$ in particular $\S 20$ of the Federal Reserve Act, I2 U.S.C. $\S 377$ (1964).
} 
banks from purchasing the stock of other corporations, except to the limited extent specified in that general prohibition.

Also significant in this connection is that, subsequent to enactment of the stockpurchase prohibition, the Congress specifically authorized banks to invest in the stock of bank service corporations. ${ }^{61}$ In the course of enacting that statute, it was indicated that, absent such a specific authorization, section 5136 of the Revised Statutes would constitute an impediment to such an investment. ${ }^{62}$

For the foregoing reasons, I am convinced that the better view (to which the Federal Reserve Board has adhered) is that the stock-purchase prohibition means that a national bank or member state bank may not separately incorporate its activities unless it is specifically authorized by statute to do so. One might argue that, since the substantive question is not an open-and-shut matter, the policy of the Congress that member state banks and national banks should be on a basis of equality in this field would justify the Board in adopting the Comptroller's view. However, as in connection with bank underwriting, the policy of equality must not be considered in a vacuum. The overriding purpose of the Banking Act of 1933 was to assure that member banks are subject to sound rules governing their activities. Experience has demonstrated that the likelihood of unsafe and unsound banking practices is greater when banks operate through subsidiary corporations than when they perform their activities themselves. Almost inevitably some banks come to regard subsidiaries as separate enterprises, and their officers and directors venture into activities that would not be permissible if performed by the bank itself.

Thus, the question in determining whether the Board of Governors is required to follow the Comptroller's interpretations in such matters has two aspects. The first involves an evaluation of the Comptroller's interpretation strictly as a legal matter. If it is considered clearly erroneous, as in the case of permitting banks to underwrite revenue bonds, the Board would be remiss in its duty if it followed such interpretation, even if the practice condoned were a sound banking practice. If the interpretation is not clearly erroneous, the question arises whether, on balance, the interpretation is sufficiently defensible that the Board should follow it despite the possibility that some of the very evils at which the particular law was directed might arise from adoption of such interpretation. In my view, only if the Comptroller's interpretation is the better legal interpretation should the Board apply it to member state banks, when doing so would open the door to those evils.

This does not mean that I consider that separate incorporation by a bank of certain of its activities is bad under all circumstances. But if it is to be permitted, it should be through legislation. Such legislation either could (I) grant general

\footnotetext{
${ }^{01} 12$ U.S.C. $\$ 1862$ (1964).

${ }^{02}$ S. REP. No. 2105, 87th Cong., 2d Sess. 5 (1962) states, "The bill would free from any limitation or prohibition otherwise imposed by any provision of Federal law, exclusively relating to banking (including, for example, I2 U.S.C. $\S 24 \ldots$. .), an investment of not more than Io percent of the paid-in and unimpaired surplus of each of the two or more investing banks."
} 
permission for the establishment of operations subsidiaries, subject to regulatory limitations, or (2) authorize the establishment only to the extent permitted by regulatory action.

Enactment by the Congress of appropriate legislation on this matter would enable both national and member state banks to operate on the basis of equality in this area, if the statute were interpreted alike by all federal supervisory agencies. But there is no certainty that that would be the case. Hence, such a solution is only a stopgap remedy, at best. A more fundamental remedy would be a reorganization of the federal bank supervisory structure to eliminate any possibility of future divergencies of supervisory policies and practices in this or any other area.

\section{III}

\section{Unification of Federal Regulation of Banking}

I first proposed unification of federal bank supervision in a Federal Banking Commission in $1962 .{ }^{63}$ Under this proposal, the bank supervisory powers now exercised by the Comptroller of the Currency and the Federal Reserve and all powers and functions now vested in the Federal Deposit Insurance Corporation would be transferred to a new independent agency, consisting of five members, who would be appointed by the President on a nonpartisan basis for staggered ten-year terms.

Unification of federal bank supervision was not a new idea. It was proposed in bills introduced in Congress as early as $1919 .{ }^{64}$ It was a subject of reports by the Brookings Institution in $1937,{ }^{65}$ the Federal Reserve in $1938,{ }^{68}$ the Hoover Commission in $1949{ }^{67}$ and the Commission on Money and Credit in $1967 .{ }^{68}$

Since 1962, a proposed Federal Banking Commission (FBC) has been the subject of bills introduced in the House of Representatives in each Congress. ${ }^{69}$ Hearings have been held before the Subcommittee on Bank Supervision and Insurance of the House Banking Committee. ${ }^{70}$ The proposal was taken up in the report of the President's Committee on Financial Institutions in $1963 .{ }^{71}$ Numerous articles and editorials have given consideration and endorsement to the idea. ${ }^{72}$

\footnotetext{
${ }^{63}$ Address, 72d Annual Convention of the Tennessee Bankers Association, Memphis, Tenn., May 16, I962.

64 S. 5537, 65th Cong., 3d Sess. (r919); 57 Cong. Rec. 2727 (1919).

${ }^{65}$ S. REP. No. 1275, 75th Cong., 1st Sess. 213-23 (1937).

${ }^{B 0} 25$ Board of Governors of the Federal Reserve System Ann. Rep. 2-I6 (1938).

${ }^{67}$ Commission on Organization of the Executive Branch of the Government, Treasury DepartMENT II-I2 (Report to Congress, r949).

${ }^{68}$ COMMISsion ON MONEY AND CREDIT, supra note 26, at I74-75.

${ }^{60}$ H.R. 5874, 88th Cong., Ist Sess. (1963); H.R. I07, 89th Cong., Ist Sess. (1965); H.R. 969, 90th Cong., Ist Sess. (1967).

${ }^{70}$ Hearings on Proposed Federal Banking Commission and Federal Deposit and Savings Insturance Board Before the Subcomm. on Bank Supervision and Insurance of the House Comm. on Banking and Currency, 88th Cong., Ist Sess. (1963) [hereinafter cited as 1963 Hearings on a Federal Banking Commission]; 1965 Hearings on Consolidation of Bank Examining and Supervisory Functions.

${ }^{71}$ Comomittee on Financiaz Institutions, Report to the President 55-64 (1963).

${ }^{72}$ E.g., Shapiro, Structural Changes in Central Banking, in Federal Reserve Bank or Boston, A Coutique of Central Banking 7 (1965); Moorhead, Is Supervisory Confusion a Congressional Problem?,
} 
Unfortunately, the FBC proposal is a matter against which emotion and certain kinds of self-interest run high and for which congressional interest runs low. If the question were the initiation of a system of federal bank supervision, no one would suggest dividing the authority among multiple agencies. But since we have a tripartite system, by historical accident, and since it has operated without obvious harm to the public welfare, the soundness and reasonableness of the proposal has been so far overcome by lethargy, by mankind's reluctance to change things, and by those who have a self-interest in maintaining the status quo. Perhaps the ultimate proposition in this direction is that "diversity in banking [bank supervision?] is a good thing."73

\section{A. Documenting the Need for Unification}

From the beginning, my reason for supporting the FBC has been that it would promote better government under law, to the benefit of all. I do not consider that the principal problems that arise from the federal tripartite arrangement are matters of the personalities of the heads of the agencies. The problems are inherent in the legislative fabric and the resulting administrative structure, which inevitably produce the confusion, supervisory conflicts, and competitive inequalities between different classes of banks that now plague our banking system.

For example, let us assume that a member state bank in Broken Bow, Nebraska, wishes to participate in the underwriting of an issue of securities. Before doing so, it must ascertain, first, whether Nebraska law and its charter grant it the power to engage in underwriting. Then it must look to rules governing members of the Federal Reserve System. In this field, as we have seen above, ${ }^{74}$ the Federal Reserve Act imposes the same limitations on member state banks that are applicable to national banks under section 5136 of the Revised Statutes; accordingly, the bank must then turn to the law governing national banks. To determine the meaning of that law, it must look first to the regulations and rulings of the Comptroller of the Currency. Because of the Board's position with respect to the applicability of the regulations and rulings of the Comptroller on bank underwriting, ${ }^{75}$ the bank must then turn back to the Federal Reserve to see whether the particular issue is eligible for underwriting in accordance with the Board's interpretation of the law. Consequently, to assure itself that it will be acting in accordance with law, the bank must consult, and attempt to follow, the current regulations of three governmental agencies.

Having two sets of rulings, one state and one federal, is consistent with the concept of our dual banking system. Having two sets of rulings at the federal level is poor

Banking, July r964, at 48; Editorial, Myopic Amid the Maze, Wall Street Journal, April 21, 1965, at I8, cols. I-2; Editorial, Regulating the Banks, N.Y. Times, May 28, I962, at 28, cols. 3-4; Hackley, Our Baffling Banking System (pt. 2), 52 VA. L. Rev. 77I, 829 (I966).

${ }^{73} 1965$ Hearings on Consolidation of Bank Examining and Supervisory Functions 212.

in See supra pp. 680-83.

${ }^{75}$ See note 34 supra. 
government. It represents an unnecessary and undesirable fragmentation of responsibility that invites confusion and opportunities for the regulated industry to play off one administrative body against the other.

Unfortunately, many federal bank supervisory functions are divided among three agencies-the Comptroller of the Currency for national banks, the Board of Governors for state-chartered banks that are members of the Federal Reserve System, and the Federal Deposit Insurance Corporation for insured state-chartered banks that are not members of the Federal Reserve System. To mitigate the evils of so fragmenting the authority, the governing statute usually contains some provision directed toward harmonious administration of the law by all three agencies. Thus, the Bank Merger Act provides that "in the interests of uniform standards" the three bank supervisory agencies shall obtain "reports on the competitive factors involved" from each other on every proposed merger. ${ }^{76}$

However, nothing resembling uniform standards on bank mergers has evolved, and this is perfectly understandable. There could hardly be anything in the law more vague, and on which three agencies are less likely to agree, than the competitive effects of a proposed merger, and there is no requirement that the approving agency's action must be affected by the views of the other agencies. ${ }^{77}$ Nevertheless, reams of paper pass back and forth monthly, however fruitless the efforts that went into them may be. If all merger applications were handled solely by one federal bank supervisory agency, uniform standards could be achieved. In addition, innumerable man-hours would be saved and substantial expense avoided, and the probabilities are that applications would be handled more expeditiously.

Ironically, the federal statutes also contain provisions that almost invite dissimilar rules at the federal level. The division of federal regulatory power affecting insured banks among the three federal bank supervisory agencies has become so sacrosanct (or so habitual) that even where the regulatory power is distinct from the supervision of banks, the power has been nevertheless allocated among them. When Congress enacted the Securities Acts Amendments of $1964{ }^{78}$ which brought some banks' securities within the coverage of the Securities Exchange Act of $1934,{ }^{70}$ it fragmented jurisdiction over securities of insured banks among the bank supervisory agencies, leaving securities of uninsured banks within the jurisdiction of the Securities and Exchange Commission. Thus, four agencies are involved, each having the power

${ }^{76} 12$ U.S.C.A. $\$ 1828$ (c) (Supp. I966).

${ }^{77}$ The Attorney General's views on the competitive factors of a proposed merger must also be requested by the bank supervisory agencies, but the approving agency's action need not be affected by those vicws any more than by the views of the other bank supervisory agencies. Id.

${ }^{78}$ Pub. L. No. $88-467,78$ Stat. 565 ( 1964 ).

${ }^{70} 15$ U.S.C. $\$ 78 l(\mathrm{i})$ (1964). There would seem to be no reason for adopting this industry approach for banks any more than for any other federally regulated industry, and the Federal Reserve accordingly opposed this aspect of the legislation. See Hearings on SEC Legislation, 1963 , Before a Strbcomm. of the Senate Comm. on Banking and Currency, 88th Cong., Ist Sess. 223 (1963); and Hearings on Investor Protection Before a Subcomm. of the House Comm. on Interstate and Foreign Commerce, 88th Cong., xst Sess. $66\left(\mathrm{Ig}^{6} \mathrm{4}\right)$. 
to promulgate different standards, forms, and other requirements despite the obvious desirability of having uniform methods of investor protection, at least with respect to securities of issuers within the same industry. Congress, moreover, has even denied the SEC the power to take the lead in protecting investors in bank securities, specifically amending the r934 act to provide that "none of the rules, regulations, forms or orders issued or adopted by the Commission pursuant to this title shall be in any way binding upon such [bank regulatory] officers and agencies in the performance of such functions." ${ }^{\text {80 }}$

Given such built-in deficiencies of the legislation on which federal bank supervision is based, the conflicts of regulations, views, rulings, and practices among the agencies are not surprising. In fact, one may wonder why conflicts are not more numerous.

Perhaps the answer to this is that much effort has been and is being expended to avoid conflicts. For example, when it became apparent in r964 that Congress was going to vest in the bank supervisory agencies jurisdiction with respect to disclosure of information on bank stocks, the FDIC and the Board of Governors began a series of interagency staff conferences, meetings with industry representatives, and joint agency meetings. Fortunately, both agencies looked at the problem of developing disclosure regulations from the view that they should implement their responsibilities relating to bank securities in a manner similar to that utilized by the Securities and Exchange Commission for corporations under its jurisdiction. ${ }^{81}$ There were nevertheless problems in coordination, in understanding, and even in approach with respect to whether, and how, certain matters should be disclosed to investors. The overriding benefits of comparability of disclosure by both member and nonmember banks (and perhaps the need to promulgate a lengthy and detailed regulation by the end of the year ${ }^{82}$ ) favored resolution of differences, and in the end identical regulations were promulgated. ${ }^{83}$

In other instances, where action is not imperative, proposals favored by one of the bank supervisory agencies may never reach the state of cooperation; they may remain stillborn. The normal practice where more than one of the agencies have regulatory authority in a particular area is for the one considering making a change to consult informally with the others before publication in the Federal Register of a notice of proposed rule making. If one of the other agencies indicates that it does not see a need for a change, or that it considers the amendment untimely (or does not respond at all), the result usually is that no further action is taken by the initiating agency.

\footnotetext{
${ }^{80}{ }_{15}$ U.S.C. $\$ 78 l$ (i) $(1964)$.

${ }^{81}$ For the policy of the Board of Governors in this connection, see 29 Fed. Reg. 2127 (I964).

82 The fiscal year of most banks coincides with the calendar year. Banks subject to the Securities Exchange Act as a result of the Securities Acts Amendments of 1964 were, therefore, required to register their securities by May I, I965. I5 U.S.C. $\$ 78 l(\mathrm{~g})(\mathrm{Ig} 64)$. To give them the benefit of the I20 days contemplated by the statute to prepare their registration statements, promulgation of regulations governing such statements by December $3 I, I 964$ was necessary.

${ }^{83}$ I2 C.F.R. pts. 206, 335 (Supp. 1966).
} 
These efforts at avoiding public conflicts, efforts which consume much time, energy, and expense, could mislead persons who are not intimately familiar with the working intricacies of federal bank supervision into believing that the supervisory agencies operate in harmony. ${ }^{84}$ The more harmful possibility, however, is that changes that would be beneficial to the general public, the banking industry as a whole, or both, may not take place.

There are, of course, many areas of open conflict. One that has recently become three-way involves the question whether absorption by a bank of so-called "exchange charges" on checks collected for its depositors constitutes an indirect payment of interest in violation of the statutory prohibition against payment of interest on demand deposits. ${ }^{85}$ For years, the Board of Governors and the FDIC have been at loggerheads on this question. The Board considers that absorption of exchange charges constitutes a payment of interest; ${ }^{86}$ the FDIC considers that it does not. ${ }^{87}$ To compound the matter, and despite the specific statutory authority of the Board of Governors "to determine what shall be deemed a payment of interest" on deposits in national banks as well as member state banks, ${ }^{88}$ the Comptroller of the Currency recently brought the conflict to a more sanguinary stage by issuing a circular letter to all national banks informing them that they "have the right-if not the duty-to absorb exchange charges for their customers in the same manner and in the same amounts as does their nonmember competition," 89 even though forbidden to do so by Federal Reserve regulations.

In a very real sense, conflicts such as these underlie the support by some bankers of the overlapping and confusing tripartite system. This situation permits them to shop around for the most lenient supervisory agency at a given time, and the unfortunate result has been appropriately described as "competition in laxity" among bank supervisors. ${ }^{90}$

Obviously, no bankers are so unsophisticated as to oppose establishment of the FBC on the ground that it would deprive them of their ability to manipulate one federal supervisory agency against another. They prefer to contend that such

${ }^{84}$ See American Banker, May 14, 1965, at I, col. I.

${ }^{80}$ I2 U.S.C. $\$ 37$ Ia $(1964)$.

${ }^{80}$ I2 C.F.R. $\$ \$ 217 . I I 7$, I20 ( 1963$)$. For a brief discussion and legislative proposal on this subject, sce 52 Board of Governors of the Federal Reserve System ANN. Rep. 240 (1965).

${ }^{87}$ I2 C.F.R. $\$ 329.2$ n. 6 (1963).

${ }^{88}$ I2 U.S.C.A. $\$ 46$ I (Supp. Ig66).

${ }^{89}$ Letter dated August 23, I966, with the caption "The following is a copy of a letter addressed to a president of a national bank." A similar action by the Comptroller occurred in December of 1963, when he informed national banks that they could accept corporate savings accounts (I2 C.F.R. $\$ 7.8$ (Supp. I966)) despite the specific authority of the Board to define the term savings deposits (x2 U.S.C.A. $\$ 46 \mathrm{I}$ (Supp. I966)) and its exercise of such authority to exclude corporations that operate for profit from the category of persons that may have such accounts in member banks (r2 C.F.R. $\$ 2$ 7.I (c) (1963)). Whether the directors of a national bank may appropriately rely on such actions by its supervisory agency in the event of legal proceedings against them for mismanagement is questionable.

${ }^{90}$ Wall Street Journal, July 6 , I966, at I8, cols. I-2. 
a Commission "would result in an undue, and potentially dangerous concentration of power in one Federal agency"11 or, more typically, that it would threaten, for one reason or another, the dual banking system.

For example, it has been suggested that the basic objective of the dual system is to protect the public against the concentration of governmental control of banking in one man or a single group of men. ${ }^{92}$ Although I do not share this view, the FBC plan is consistent with it. Each insured state bank would remain subject to supervision by both a state and a federal board-type agency. A national bank, which is principally under the supervision of one administrator today, would become subject to the supervision of a commission of five members.

In the final analysis, as I have pointed out before, enactment of the FBC bill would tend to strengthen rather than jeopardize the dual banking system. ${ }^{93}$ State bank supervisors and their association would find it possible, for the first time, to solve problems common to state and national banks, member banks of the Federal Reserve System and nonmembers, by working with a single federal agency.

We must remember that, with only rare exceptions, a bank's powers are derived solely from the government that granted its charter. Numerous federal laws limit a state-chartered bank in the exercise of its powers, particularly if it wishes to have the benefits of federal deposit insurance or membership in the Federal Reserve System. Unification of the federal bank supervisory agencies would have no effect whatsoever on a bank's powers; it would, however, assure that the exercise of certain of its powers and the exercise of the same powers by national banks would be subject to the same rules. In interpreting a law that limits the activities of both national and state-chartered banks, it is inconceivable that the Commission would apply one interpretation to one class and a different interpretation to the other, any more than the FDIC or Federal Reserve System has discriminated between state and national banks.

\section{B. Who Should Be the Repository of Unified Authority?}

Once the idea of unification of federal bank supervision is accepted as the only reasonable solution to the structural defects and consequent shortcomings of federal bank supervision, thoughtful consideration must be given to the questions that arise in deciding upon the locus of unification. For example, since increased efficiency is one of the purposes of unification, why not centralize the authority in one person? Admittedly, one-man administration is usually swifter and more immediately effective than a board of five members. On the other hand, the relatively cumbersome deliberations of a body composed of five members are more likely, in my judgment,

\footnotetext{
${ }^{01} 1963$ Hearings on a Federal Banking Commission 266.

${ }_{02}^{02} 1965$ Hearings on Consolidation of Bank Examining and Supervisory Functions 182.

${ }^{03}{ }_{1963}$ Hearings on a Federal Banking Commission 178.
} 
to develop policies and to result in decisions that will enable the banking industry to make its optimum contribution to the economy.

But if a board-type administration is preferable to a one-man administration, some have asked, why not centralize authority in the Federal Reserve, which has had over fifty years of experience in bank supervision? Most proposals for unification have favored the Federal Reserve as the locus, ${ }^{94}$ and one would expect that an existing agency would tend to look favorably upon proposals to expand its jurisdiction. Perhaps this is why my support of a transfer of Federal Reserve responsibilities in the area of bank supervision to the new FBC has been described as "interesting."

As a practical matter, I believe it would be seriously detrimental to place in the Board the important additional responsibilities that would accompany unification. There are limits to man's ability effectively to perform his assigned duties. In our complex society, merely keeping informed of what is going on in the national economy is becoming more and more difficult. Developing and implementing appropriate monetary policy at a given time require consideration and evaluation of the significance of an enormous volume of available data and their interrelationships. The responsibilities are of such magnitude that the Board should not be also burdened with the performance of bank supervisory functions. Supervision is too important a function in itself to be the Federal Reserve's part-time job.

The overriding reason, however, for seeking to have the supervisory powers vested elsewhere than in the Federal Reserve is my deep-seated conviction that bank examiners should always be free to call the pitches as they see them. They should be insulated from any possible temptation of the monetary authority to use supervisory powers to implement monetary policy by appraising loans with a more critical eye in periods of tight money, when monetary policy is seeking to curb credit expansion, and a less critical eye in periods of easy money, when the aim of monetary policy is to expand the money supply. As a matter of fact, the "bad" loans are not made in periods of tight money, because the banks have barely enough funds then to meet demands of the most credit-worthy customers; rather "bad" loans usually originate when banks are stretching out to put idle funds to work.

Divorcing the Federal Reserve from bank supervision would in no way diminish its ability to keep abreast of banking developments. Information about banking practices would be just as available to the Board if supervision were unified in the FBC. To assure that the Board of Governors would have access to all reports of examination and reports of condition accepted by the Commission, I have recommended that the law require the Commission to furnish such reports to the Federal Reserve System. ${ }^{95}$ It would be absurd to believe that examiners in the employ of the

\footnotetext{
94 The initial effort in this direction was a bill introduced by Senator Weeks in r9rg. S. 5537, 65th Cong., 3d Sess. (19I9), 57 Cong. Rec. 2727 (I9I9).

${ }^{\circ 5} 1965$ Hearings on Consolidation of Bank Examining and Supervisory Functions 87.
} 
Federal Reserve would be able to provide information that would be more valuable to the formulation of monetary policy than examiners employed by the FBC.96

To the extent that unification in the Federal Reserve might permit decentralization of authority, such as by utilization of the thirty-six offices of the Federal Reserve Banks, such opportunities, and resulting economies, would be equally available under the FBC. Both the Comptroller of the Currency and the FDIC have a system of regional offices. Under the FBC, these offices and the offices of the Reserve Banks could be utilized just as effectively as if bank supervision were unified in the Federal Reserve. Decentralization would depend in both cases solely on the willingness of the agency to delegate its functions. Provisions of the FBC bill specifically authorize broad delegation of authority. ${ }^{97}$

\section{Means of Accomplishing the Needed Reform}

Apart from the merits of unification and questions relating to the locus, there is also the problem of the legislative road toward the desired goals. So far, the efforts have been geared to what may be described for this purpose as positive legislation-that is, congressional enactment. While such legislation is the only way to achieve the FBC as it was originally conceived and as it is reflected in the bills that have been introduced, unification could also be accomplished by a reorganization plan submitted by the President for tacit congressional acceptance. ${ }^{98}$

As a practical matter, much can be said for using such a vehicle to reach unification. The bill to create the FBC is ninety-eight printed pages; a reorganization plan probably could be contained in three. In this hectic period, the Congress has little time to devote to what, after all, is a matter of good administrative organization. When it enacted the Reorganization Act of $1949{ }^{99}$ it both acknowledged the need for

${ }^{\circ 0}$ The Board is authorized by section $\operatorname{Ir}(\mathrm{a})$ of the Federal Reserve Act to make examinations of all member banks. I2 U.S.C. $\$ 248$ (a) ( $(964)$. As a general practice, it does not examine national member banks, which are examined by the Comptroller of the Currency. If I believed, which I do not, that the ability of the Federal Reserve System to formulate monetary policy was substantially affected by whether the bank examiners were employed by it or some other agency, I would recommend that we make full use of our existing powers.

${ }^{07}$ H.R. 107, 89th Cong., Ist Sess. $\$ 9$ (I965).

${ }^{88}$ Submission of such a plan is authorized by 5 U.S.C.A. $\$ 903$ (Special Pamphlet I966). It would become effective 60 days thereafter, unless the majority of the membership of one of the Houses approved a resolution against it. 5 U.S.C.A. $\$ 906$ (Special Pamphlet 1966). One major difficulty with a reorganization plan to accomplish unification of federal bank supervision is that the commissioners' terms of office could not be more than four years. 5 U.S.C.A. \$ 904 (Special Pamphlet 1966). Another is that the examining personnel of the Federal Reserve Banks that would be transferred to the Commission probably could not be given credit under the Civil Service Retirement System for their bank service. They are not presently covered by Civil Service. To provide that their service is "creditable service" for the purposes of Civil Service Retirement (5 U.S.C.A. $\$ 8332$ (Special Pamphlet I966)) and to levy a special assessment on the Reserve Banks to make up the federal agency "matching" payment to the Civil Service fund (5 U.S.C.A. $\$ 8334$ (Special Pamphlet 1966)) would appear to require legislation, because a reorganization plan may not have the effect of "authorizing an agency to exercise a function which is not expressly authorized by law at the time the plan is transmitted to Congress." 5 U.S.C.A. \$905(a)(4) (Special Pamphlet r966).

${ }^{99}$ Ch. 226, 63 Stat. 203 (I949). 
efficient government and provided a means for accomplishing organizational changes relatively free from the political process. By periodic extension of the act, $^{100}$ it renewed these determinations. Unification of the bank supervisory agencies

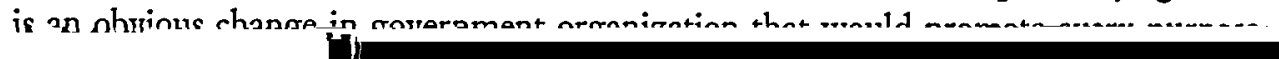


complex society. Laws may be repressive, but in our system of government, when an administrator-or any citizen-considers that the burden of law should be alleviated, his remedy is to seek corrective legislative action.

At times, the legislative remedy may appear illusory and elusive. This seems particularly true when we believe that we have developed a sound and workable solution to an obvious problem but are unable to make much headway toward enactment of the necessary legislation. Occasionally we may come close to losing faith in our governmental mechanism.

For several years now, I have been convinced that the Federal Banking Commission plan is a most worthwhile legislative proposal. It would (I) eliminate wasteful duplication, overlapping, and never-ending efforts to coordinate agencies' actions, (2) end much friction and conflict among banks and bank supervisors, (3) enable the banking industry to operate under a single consistent set of rules-in an environment of competitive equality -as far as federal supervision is concerned, (4) do away with a dangerous tendency toward laxity in bank supervision that leads to disregard of legal requirements and to deterioration of the standards of sound banking which it is the function of bank supervision to enforce and maintain, and (5) enable the Federal Reserve Board to devote its time and attention exclusively to its most vital function-the formulation and implementation of monetary policy. ${ }^{102}$

Despite some frustration over the absence of action in this direction, I am not discouraged. In fact, I have been gratified by much articulate support from persons who are genuinely interested in the betterment of our governmental procedures, our banking system, and the general welfare. Let us hope it will not take a catastrophe, or a series of them, to develop the necessary momentum. Sooner or later a reformation of federal banking regulation will become even more obviously essential, and will come about.

In the meantime, we must continue to accommodate to our hodgepodge regulatory structure and mechanisms, and to develop and promote supporting legislation that is directed toward making the existing tripartite regulatory scheme more workable. While we endeavor to attain the best federal bank supervision that reason can develop, through unification and other fundamental changes, we must not relax our obligation to make the present system, however faulty, as effective as possible without abandoning our vital tradition of obedience to law.

\footnotetext{
${ }^{102}$ Compare these reasons for supporting the Federal Banking Commission with the purposes of executive reorganization, note IOI supra. These reasons and those purposes would be served to an even greater extent by unification in one agency of the private financial institution supervisory functions of the following: the Comptroller of the Currency, the Board of Governors of the Federal Reserve System, the Federal Deposit Insurance Corporation, and the Federal Home Loan Bank Board. It has become clear, with the expanding powers of thrift institutions and their increased competition with commercial banks, that the only sensible scheme of federal regulation of both types of institutions is through the same supervisory agency.
} 